\title{
Hydraulic architecture of lianas in a semiarid climate: efficiency or safety?
}

\author{
Ellen Cristina Dantas Carvalho ${ }^{1^{*}}$, Fernando Roberto Martins ${ }^{2}$, Arlete Aparecida Soares ${ }^{3}$, \\ Rafael Silva Oliveira ${ }^{2}$, Celli Rodrigues Muniz ${ }^{4}$ and Francisca Soares Araújo ${ }^{3}$
}

Received: September 15, 2014 Accepted: November 27, 2014

\begin{abstract}
Xylem anatomical traits can provide insights regarding the mechanisms affecting the distribution of vascular plants across environmental gradients. In this study, we aimed to investigate the hypothesis that lianas occurring in semiarid environments have characteristics that maximize the xylem resistance to tension-induced cavitation along the root-stem-branch continuum. To gather information regarding the hydraulic architecture of the lianas, we analyzed several anatomical traits of wood: cross-sectional area occupied by the parenchyma $\left(A_{\mathrm{p}}\right)$, fibers $\left(A_{\mathrm{F}}\right)$, and vessels $\left(\mathrm{A}_{\mathrm{v}}\right)$; average vessel diameter (d); wood density (WD); pit diameter in the vessel wall ( $\left.\mathrm{d}_{\mathrm{pit}}\right)$; pit density $\left(\mathrm{N}_{\mathrm{pit}}\right)$, and potential hydraulic conductivity $(\mathrm{Kp})$ in branches, stems, and roots of three congeneric species of lianas that occur in two vegetation types of the semiarid regions of Brazil. We found that lianas in these semiarid environments possess a number of the following xylem traits that may allow resistance to tension-induced cavitation:1) lower vessel diameter, lower K $p$, and higher hydraulic safety in roots and branches; 2) Dimorphic vessels, ensuring both hydraulic efficiency and safety; and 3) small diameter of pits (potentially associated with a decrease in the membrane area of the vessel pits). This suite of traits may provide insight into mechanisms allowing lianas to occur in semiarid environments.
\end{abstract}

Keywords: potential hydraulic conductivity, vessel diameter, wood anatomy, wood density, xylem

\section{Introduction}

Plant hydraulic architecture can be defined as the set of parenchyma, fibers, and vessel elements or tracheids that are involved in water transport through the soil-plantatmosphere continuum (Hacke \& Sperry 2001). Differences in the spatial pattern and proportions of these tissues may result in different consequences for water absorption and use by the plant (Tyree \& Ewers 1991). Hence, analysis of plant hydraulic architecture may indicate how water availability shapes plant form and function (Tyree \& Ewers 1991; Bucci et al. 2004).

Several anatomical and morphological characteristics of the xylem can be used to infer about the hydraulic safety and efficiency of plants (Choat et al. 2005; Poorter et al. 2010; Jacobsen et al. 2012). Wood density (WD) has been shown to influence hydraulic conductivity (Bucci et al. 2004) as well as the resistance to drought-induced embolism and water storage capacity in the xylem (Pratt et al. 2007; Jacobsen et al. 2008; Chave et al. 2009; Zanne et al. 2010).
Differences in WD may be determined by variations in the dimensions and proportions of the vessels, fibers, and parenchyma (Poorter et al. 2010; McCulloh et al. 2012). Generally, species with high WD have narrow vessels, high proportion of fibers, and a low amount of parenchyma (Zanne et al. 2010). These characters should reduce the hydraulic conductivity and increase the xylem resistance against embolism in comparison to species with low WD (Choat et al. 2005; McCulloh et al. 2011).

In addition, anatomical characteristics of vessel pits are important for resistance to drought-induced embolism (Hacke et al. 2006). The pits allow the flow of water between vessels and adjacent non-conducting cells, and they can prevent the entry of air into functional vessels (Hacke \& Sperry 2001). According to the air-seeding hypothesis (Zimmermann 1983), cavitation occurs when the outside air enters functional vessels through the vessel pits. Hacke et al. (2006) showed that the increase in resistance to drought-induced cavitation was correlated with the decrease in the membrane area of the vessel pits in many species and growth forms.

\footnotetext{
${ }^{1}$ Programa de Pós-graduação em Ecologia e Recursos Naturais, Universidade Federal do Ceará, 60020-181, Fortaleza, CE, Brazil

${ }^{2}$ Departamento de Biologia Vegetal, Instituto de Biologia, Universidade Estadual de Campinas, 13083-970, Campinas, SP, Brazil

${ }^{3}$ Departamento de Biologia, Centro de Ciências, Universidade Federal do Ceará, 60020-181, Fortaleza, CE, Brazil

${ }^{4}$ Embrapa Agroindústria Tropical, 60511-110, Fortaleza, CE, Brazil

*Corresponding author: ellencarvalho.bio@gmail.com
} 
In lianas, the xylem shows cambial variations that are assumed to be adaptations related to the climbing habit of these plants, including wide vessels, high proportion of parenchyma, and low amount of fibers (Carlquist 1985; Brandes \& Barros 2008). Although wide vessels provide greater hydraulic conductivity to lianas than other growth forms, they may also decrease their hydraulic safety (Gartner et al. 1990; Ewers et al. 1997; McCulloh \& Sperry 2005; Gutierréz et al. 2009). The low amount of fiber increases the flexibility of the stem (Carlquist 1985; Brandes \& Barros 2008; Carlquist 2012) and decreases the risk of mechanical damage to the xylem (Carlquist 2012). On the other hand, the significant amount of parenchyma can increase the capacity to store water in the stem (Martínez-Cabrera et al. 2009).

Low water availability in semiarid environments results in greater risks of embolism and cavitation in conducting vessels of vascular plants and can potentially prevent the establishment of drought-sensitive species (Sperry \& Hacke 2002). Unlike lianas, trees and shrubs that occur in semiarid habitats tend to be smaller, have short and narrow vessels, high proportion of fibers, and high WD that increases the resistance to cavitation but reduces hydraulic conductivity (Hacke \& Sperry 2001; Hacke et al. 2006; Mitchell et al. 2008). Lianas are presumably sensitive to soil water depletion; however, few studies have investigated the anatomical characteristics of the hydraulic system of lianas that occur in seasonally dry environments (Brandes \& Barros 2008; Pace et al. 2009; Angyalossy et al. 2012). In addition, although the xylem hydraulic architecture of liana roots is still unknown, it can provide important insights to explain the hydraulic functioning of liana species in semiarid zones (Carlquist 1989; Choat et al. 2005; Poorter et al. 2010; Gea-Izquierdo et al. 2012).

Our goal was to investigate the hypothesis that lianas occurring in semiarid environments have characteristics that maximize the xylem resistance to drought-induced cavitation along the root-stem-branch continuum. To provide insight into the possible mechanisms and strategies of the whole-plant hydraulic functioning, we analyzed the hydraulic architecture of three congeneric species of lianas that occur in two vegetation types of the Brazilian semiarid tropical zone. We measured the anatomical characteristics of the xylem that are related to efficiency and safety in water transport: $\mathrm{WD}$; cross-sectional area occupied by the parenchyma $\left(A_{p}\right)$, fibers $\left(A_{F}\right)$, and vessels $\left(A_{v}\right)$; vessels density $(N)$; vessel average diameter $(d)$ and maximum diameter $\left(\mathrm{d}_{\max }\right)$; vessel hydraulic diameter $\left(\mathrm{D}_{h}\right)$; hydraulic conductivity potential $(\mathrm{K} p)$; pit diameter in the vessel wall $\left(\mathrm{d}_{\text {pit }}\right)$; and pit density $\left(\mathrm{N}_{\text {pit }}\right)$ in branches, stems, and roots. Variations in xylem anatomical characters can lead to differences in the hydraulic performance across species (McCulloh et al. 2010) and can provide insights about the mechanisms that allow lianas to occur in semiarid environments.

\section{Material and methods}

\section{Study area and focal species}

We collected lianas in two vegetation types which are regionally known as caatinga and carrasco. Both vegetation types grow in a semiarid climate and have different richness and abundance of lianas (Araújo \& Martins 1999; Araújo et al. 2011). The study areas are located within the Serra das Almas Private Natural Heritage Reserve ( $5^{\circ} 7^{\prime} 001^{\prime \prime} S$ and $40^{\circ} 52^{\prime} 220.79^{\prime \prime} \mathrm{W}$ ), which is in the mid-western region of the state of Ceará and is located in the northeastern semiarid region of Brazil.

The caatinga, a deciduous thorny savanna, occurs on terrains of the crystalline basement complex at altitudes from 300 to $400 \mathrm{~m}$ a.s.l. (Costa \& Araújo 2012). The annual average temperature is $27^{\circ} \mathrm{C}$, and the average annual rainfall is $698 \mathrm{~mm}$, of which $84 \%$ is concentrated from January to April (Costa \& Araújo 2012). The soil is a Leptosol (FAO 2006), which corresponds to clayey, shallow, and rocky soils. The carrasco, a dense deciduous shrubby vegetation, occurs at higher altitudes (700-900 m a.s.l.) on an Arenosol (FAO 2006), which corresponds to sandy, deep, and nutrient-poor soils (Araújo \& Martins 1999; Vasconcelos et al. 2010). The average annual temperature is $26^{\circ} \mathrm{C}$, and the average annual rainfall varies from 668 to $1289 \mathrm{~mm}$; the rainfall is also concentrated from January to April (Vasconcelos et al. 2010).

Because we did not observe any species that was common to both vegetation types, we selected three congeneric species of the family Bignoniaceae, tribe Bignonieae, and genus Fridericia Mart. In the carrasco, we selected Fridericia chica (Bonpl.) L. G. Lohmann and Fridericia dispar (Bureau ex K. Schum.) L. G. Lohmann. In the caatinga, we recorded only Fridericia caudigera (S. Moore) L. G. Lohmann. We selected congeneric species for our analysis because, according to Wiens \& Graham (2005), strictly related species tend to occupy similar habitats and use similar environmental resources, i.e., related species tend to share similar ecological niches because of phylogenetic conservatism. Thus, we considered these species as suitable models to assess hydraulic functioning through wood anatomy.

\section{Hydraulic architecture, wood density, and conductivity}

We selected adult lianas approximately $6-\mathrm{m}$ tall and a stem perimeter at ground level between 9 and $12 \mathrm{~cm}$ to collect samples for anatomical analysis. We collected samples of branches, stems at $2 \mathrm{~m}$ above ground level, and shallow roots at $1 \mathrm{~m}$ distant from the stem in five individuals of each species. To measure WD, we collected a disk from the stem at $1.5 \mathrm{~m}$ above the ground level of each individual and determined WD as the ratio between dry mass and water volume $\left(\mathrm{g} \mathrm{cm}^{-3}\right)$ following the protocol by Barbosa \& Fearnside (2004). 
For the anatomical measurements, we fixed samples of branches, stems, and roots in 50\% FAA as soon as they were collected. Stem samples were first sectioned using a sliding microtome into $20-\mu \mathrm{m}$ thick sections, which were cleared with sodium hypochlorite, washed in distilled water, and stained with $1 \%$ astra blue and $1 \%$ safranin (Gerlach 1984). Following this, the sections were dehydrated in increasing ethanol series and mounted on slides with synthetic resin. Samples of branches and roots were dehydrated in increasing ethanol series and embedded in Leica Historesin. Sections of $8 \mu \mathrm{m}$ in thickness were cut with a Leica 2065 rotary microtome and then stained with toluidine blue and fuchsine (Junqueira 1990) and mounted on slides with synthetic resin.

We analyzed the slides under a Leica DM 4000B LED microscope equipped with an image capture system. To standardize the measurements among species, we selected five growth rings from the outside in, and in that area, we measured the diameter and area of each vessel and the areas occupied by parenchyma, fibers, and vessels, using the software Image J 1.44 (http://imagej.nih.gov/ij/).

To measure vessel pits, lengthwise sections of xylem samples of the branches, stems, and roots were dehydrated in an ethanol series, dried at $37^{\circ} \mathrm{C}$, mounted on aluminum stubs, and platinum coated using Emitech apparatus. The samples were analyzed with a Digital Scanning Electron Microscope (Zeiss DSM 940 equipped with digital image capture). For each analyzed organ (branches, stem, and roots), we measured $\mathrm{N}_{\text {pit }}$ and $\mathrm{D}_{\text {pit }}$ in five vessels of organ/ individual using Image J software 1.44 (http://imagej.nih. gov/ij/).

We calculated the $\mathrm{K} p$ following the Hagen-Poiseuille law (Poorter et al. 2010):

$$
\mathrm{K} p=(\pi \rho w / 128 \eta) \times \mathrm{N} \times D_{h}^{4}
$$

where, $\mathrm{K} p$ is the potential specific conductivity (in $\mathrm{Kg} \mathrm{m}$ $\left.\mathrm{MPa}^{-1} \mathrm{~s}^{-1}\right), \rho_{w}$ is the water density at $20^{\circ} \mathrm{C}\left(998.2 \mathrm{~kg} \mathrm{~m}^{-3}\right)$, $\eta$ is the water viscosity at $20^{\circ} \mathrm{C}\left(1.00210^{-3} \mathrm{~Pa} \mathrm{~s}^{-1}\right), \mathrm{N}$ is the vessel density, and $\mathrm{D}_{h}$ is the hydraulic diameter of vessel (in $\mathrm{m})$. We calculated the $\mathrm{D}_{h}$ of each vessel because the shape of the vessels was not a perfect circle. We calculated $\mathrm{D}_{h}$ using the following formula:

$$
D_{h}=\left[(1 / \mathrm{n}) \sum_{i=1}^{n} d^{4}\right]^{1 / 4}
$$

where. is the number of vessels and is the diameter of vessels.

Finally, we evaluated cambial variation according to the classification for Bignonieae proposed by Pace et al. (2009).

We performed the statistical analysis using the programs PAST version 1.79 (Hammer et al. 2001) and R version 2.15.1 (http://www.r-project.org/). We used the ShapiroWilk test to test for data normality. We transformed the data into $\log _{10}$ for standardization when necessary. We used the Fisher test $(p<0.05)$ to analyze the data of $\mathrm{d}$ and Kp be- cause the samples had different sizes. We analyzed the data of WD, $\mathrm{N}, \mathrm{d}_{\text {pit }}$, and $\mathrm{N}_{\text {pit }}$ in the vessel wall using a one-way analysis of variance (ANOVA) $(p<0.05)$. We performed linear regression and Pearson's correlation analyses between the WD data and $A_{p}, A_{F}, A_{v}$. We related the $K p$ to $D_{h}, A_{v}$, and $\mathrm{N}$ through a polynomial regression and Spearman correlation coefficient.

\section{Results}

We observed a wide range of $d$ in all three liana species (Fig. 1A-C), and vessels with both large and small diameters (dimorphic vessels) were present in the branches, stems, and roots of each species. Consistent variation in $d$ was observed along the plant in all three species (Tab. 1). Roots and branches had narrower vessels than the stems (Tab. 1). Only $F$. chica showed no differences in d between roots and stems $(p=0.08)$. The maximum vessel diameter $\left(\mathrm{d}_{\max }\right)$ was largest (over $200 \mu \mathrm{m}$ ) in stems and did not exceed $130 \mu \mathrm{m}$ in branches and roots (Tab. 1). The diameter distribution of vessels was similar in all species (Fig. 1A-C). Branches and roots had narrower vessels, which were concentrated in the first diameter classes (Fig. 1A, C). Although we observed wide vessels in the stems, the highest number of vessels was found in the smaller diameter classes (Fig. 1B).

$\mathrm{N}$ in F. caudigera was higher in the roots and branches and lower in the stem (Tab. 1). Fridericia dispar showed a lower $\mathrm{N}$ in roots and the stem and a higher vessel density in the branches. The vessel density was higher in the stem and lower in roots and branches in F. chica (Tab. 1). The branches $(\mathrm{F}=0.9463 ; p=0.4153)$ and roots $(\mathrm{F}=3.291$; $p=0.0758)$ did not differ in vessel density among species. Fridericia chica showed higher density of vessels only in the stem (Tab. 1$)$ and differed from $F$. caudigera $(\mathrm{F}=7.988$; $p=0.0004)$ and $F$. dispar $(\mathrm{F}=5.056 ; p=0.01)$. We did not find differences in the stem vessel density between $F$. caudigera and $F$. dispar $(\mathrm{F}=2.932 ; p=0.13)$.

The occurrence of many vessels in the first classes of diameter indicates low $\mathrm{K} p$ values, whereas the occurrence of a few vessels in the last classes of diameter indicates high $\mathrm{K} p$ values (Fig. $1 \mathrm{D}-\mathrm{F}$ ). In all species, $\mathrm{K} p$ showed positive correlations with hydraulic diameter $\left(\mathrm{D}_{h}\right)\left(\mathrm{r}^{2}=0.89\right.$; $\rho=+0.93)$ and $\mathrm{A}_{\mathrm{V}}\left(\mathrm{r}^{2}=0.74 ; \rho=+0.94\right)$ (Fig. 2A-B). $\mathrm{D}_{h}$ and $\mathrm{A}_{\mathrm{V}}$ were positively related to $\mathrm{K} p$. Because $\mathrm{A}_{\mathrm{V}}$ is directly related to $\mathrm{d}$, we can consider it a dependent variable; therefore, it has the same behavior as $\mathrm{D}_{h}$ with $\mathrm{K} p$. Because of dimorphism in liana vessels (wide and very narrow vessels together), we did not find a linear relationship between $\mathrm{D}_{h}$ and $\mathrm{K} p$ (Fig. 2A). We also observed a positive correlation between $\mathrm{K} p$ and $\mathrm{N}\left(\mathrm{r}^{2}=0.05 ; \rho=+0.27\right)$ but with low explanatory power (Fig. 2C).

All species showed low $\mathrm{K} p$ in branches and roots and high $\mathrm{K} p$ in stems (Tab. 1). Small differences in d led to large differences in $\mathrm{K} p$. This occurs because the conductivity of a given vessel is equivalent to the fourth power of its diameter 

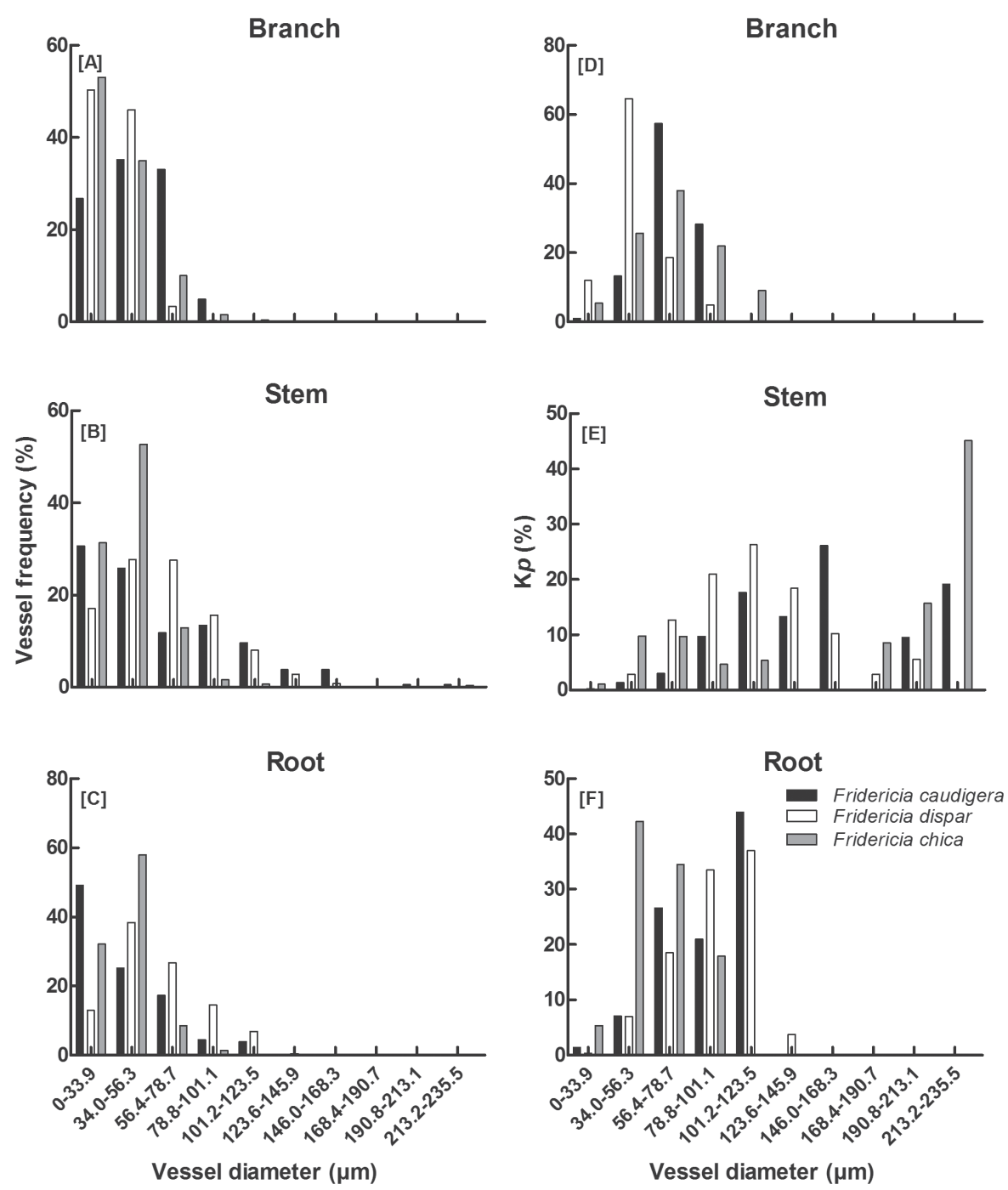

Figure 1. Vessel diameter frequency distribution in branches (A), stem (B), and roots (C). Percentage of hydraulic conductivity potential $\left(\mathrm{K}_{p}\right)$ per diameter class in branches (D), stems (E), and roots (F) of the species Fridericia caudigera, F. dispar, and F. chica.

Table 1. Characteristics of the xylem of lianas (Fridericia caudigera, $F$. dispar, and $F$. chica in a semiarid environment). WD $=$ wood density, $\mathrm{A}_{\mathrm{p}}=\mathrm{cross}$-sectional area occupied by parenchyma (\%), $\mathrm{A}_{\mathrm{F}}=$ cross-sectional area occupied by fibers (\%), $\mathrm{A}_{\mathrm{v}}=$ cross-sectional area occupied by vessels $(\%), \mathrm{d}=$ vessel average diameter, $\mathrm{d}_{\max }=$ maximum diameter, $\mathrm{N}=$ vessel density per $\mathrm{mm}^{2}, \mathrm{~K}_{p}=$ hydraulic conductivity potential, $\mathrm{d}_{\text {pit }}=$ pit diameter, $\mathrm{N}_{\mathrm{pit}}=$ pit density (mean \pm standard deviation).

\begin{tabular}{|c|c|c|c|c|c|c|c|c|c|c|}
\hline \multicolumn{11}{|c|}{$\begin{array}{c}\text { Caatinga } \\
\text { Fridericia caudigera }\end{array}$} \\
\hline & $\underset{\left(\mathrm{g} \mathrm{cm}^{-3}\right)}{\mathrm{WD}}$ & $A_{p}(\%)$ & $A_{F}(\%)$ & $A_{v}(\%)$ & $d_{\max }(\mu \mathrm{m})$ & $\mathrm{d}(\mu \mathrm{m})$ & $\mathbf{N}\left(\mathbf{m m}^{-2}\right)$ & $\begin{array}{l}\mathrm{Kp}(\mathrm{Kg} \mathrm{m} \\
\left.\mathrm{MPa}^{-1} \mathrm{~s}^{-1}\right)\end{array}$ & $\mathrm{d}_{\mathrm{pit}}(\mu \mathrm{m})$ & $\mathrm{N}_{\text {pit }}\left(\mathrm{mm}^{-2}\right)$ \\
\hline Branch & - & 47.8 & 39.4 & 12.6 & 98.9 & $47.6 \pm 1.6$ & $60.9 \pm 9.5$ & $16.1 \pm 3.3$ & $1.6 \pm 0.1$ & $21730.9 \pm 1371.6$ \\
\hline Stem & 0.5098 & 51.2 & 28.2 & 20.4 & 235.5 & $63.3 \pm 2.9$ & $44.4 \pm 4.2$ & $96.0 \pm 31.0$ & $1.4 \pm 0.4$ & $18421.7 \pm 1284.2$ \\
\hline Root & - & 61.2 & 18.3 & 20.3 & 123.1 & $42.2 \pm 1.8$ & $123.8 \pm 34.6$ & $37.7 \pm 17.1$ & $1.6 \pm 0.1$ & $21351.1 \pm 1435.3$ \\
\hline \multicolumn{11}{|c|}{$\begin{array}{c}\text { Carrasco } \\
\text { Fridericia dispar }\end{array}$} \\
\hline Branch & - & 44.8 & 45.9 & 9.1 & 78.7 & $34.7 \pm 0.5$ & $88.1 \pm 22.9$ & $5.2 \pm 1.6$ & $1.2 \pm 0.2$ & $29261.1 \pm 1878.4$ \\
\hline Stem & 0.4933 & 49.3 & 23.7 & 26.8 & 201.2 & $64.0 \pm 1.1$ & $69.8 \pm 4.4$ & $77.5 \pm 18.6$ & $1.5 \pm 0.2$ & $16361.9 \pm 547.1$ \\
\hline Root & - & 58.7 & 21.9 & 19.3 & 127.2 & $60.0 \pm 1.5$ & $63.5 \pm 6.8$ & $38.1 \pm 10.4$ & $1.2 \pm 0.2$ & $21930.1 \pm 738.7$ \\
\hline \multicolumn{11}{|c|}{ Fridericia chica } \\
\hline Branch & - & 40.9 & 52.4 & 7.4 & 104.0 & $36.9 \pm 0.9$ & $60.8 \pm 12.7$ & $6.79 \pm 2.7$ & $1.1 \pm 0.2$ & $26887.1 \pm 1728.4$ \\
\hline Stem & 0.5248 & 43.9 & 36.9 & 19.1 & 232.0 & $43.8 \pm 0.8$ & $113.5 \pm 13.6$ & $52.4 \pm 37.7$ & $1.6 \pm 0.08$ & $16563.4 \pm 669.2$ \\
\hline Root & - & 57.7 & 33.0 & 9.1 & 96.0 & $41.3 \pm 0.8$ & $64.2 \pm 9.5$ & $7.0 \pm 1.9$ & $1.1 \pm 0.2$ & $27005.4 \pm 2084.7$ \\
\hline
\end{tabular}



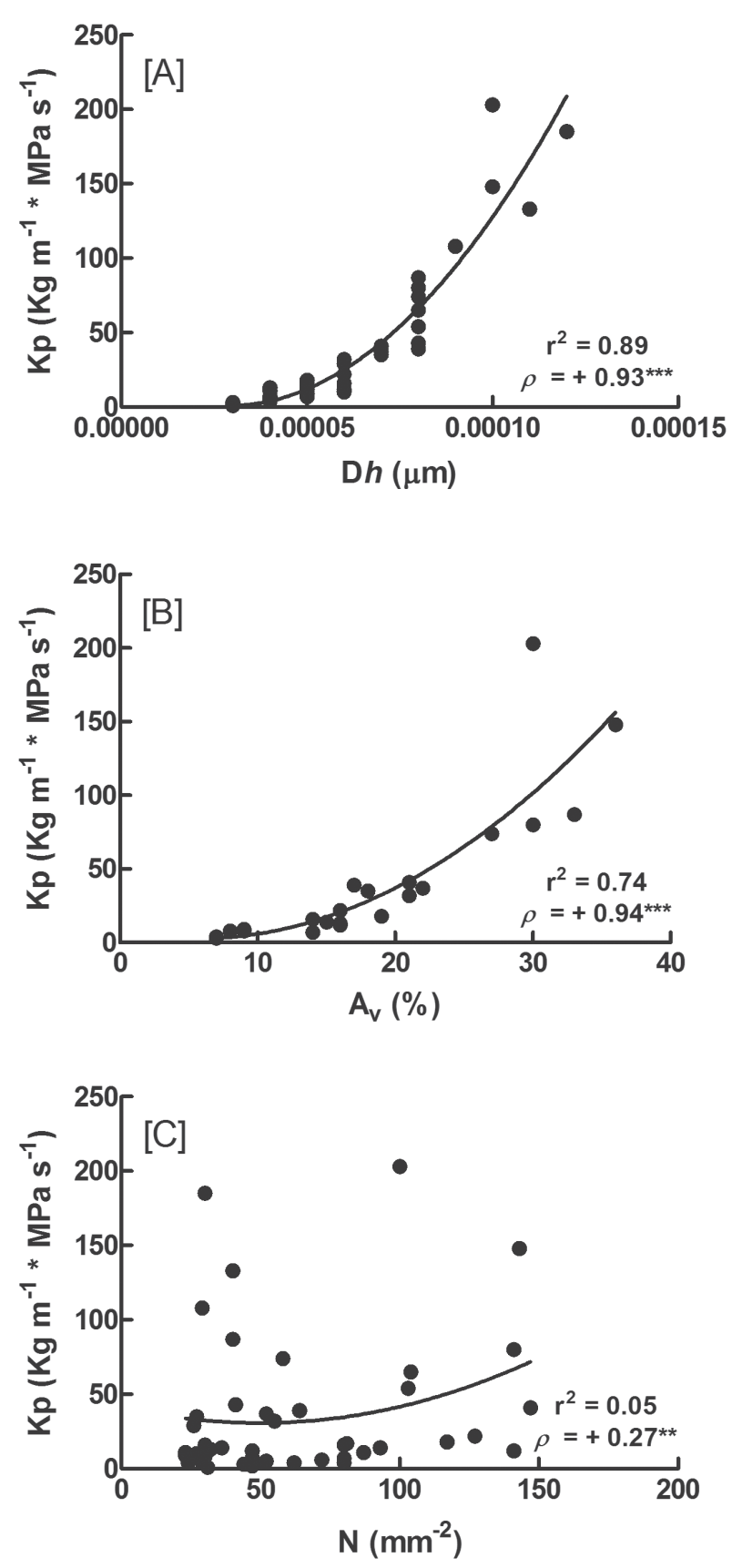

Figure 2. Relationship between hydraulic conductivity potential $(\mathrm{K} p)$ and vessel measurements: (A) hydraulic diameter $\left(D_{h}\right),(B)$ cross-sectional area occupied by vessels $\left(\mathrm{A}_{\mathrm{V}}\right)$ and $(\mathrm{C})$ vessel density $(\mathrm{N})$ in Fridericia caudigera, F. dispar, and F. chica. Polynomial regressions, Spearman correlations $(\rho)$, and significance levels $\mathrm{P}<0.01\left(^{* *}\right)$ and $\mathrm{P}<0.001\left(^{* * *}\right)$ are shown.

(Law of Hagen-Poiseuille). Hence, small vessels in roots and branches showed a stronger decrease in $\mathrm{K} p$ than the vessels in the stem (Tab. 1).

All species showed intervascular, bordered, alternate, and non-vestured pits (Fig. 3). The $\mathrm{d}_{\text {pit }}$ in F. caudigera was similar in the branches, stem, and roots $(\mathrm{F}=2.489$; $p=0.19 ;$ Tab. 1). The $\mathrm{d}_{\text {pit }}$ was higher in the stem in relation to the branches and roots in F. dispar and F. chica, $(\mathrm{F}=14.09$, $p<0.0001 ; \mathrm{F}=38.53, p<0.0001$, respectively; Tab. 1 ). Both $F$. dispar and $F$. chica showed no difference in the $\mathrm{d}_{\text {pit }}$ between branches and roots $(\mathrm{F}=1.396, p=0.58 ; \mathrm{F}=1.644, p=0.47$, respectively). Among the species, $F$. caudigera showed a higher $\mathrm{d}_{\text {pit }}$ in the branches and roots (Tab. 1) than the $\mathrm{d}_{\text {pit }}$ of $F$. dispar $(\mathrm{F}=5.057, p<0.0001 ; \mathrm{F}=6.999, p<0.0001$, respectively) and F. chica $(\mathrm{F}=6.082, p<0.0001 ; \mathrm{F}=8.714, p$ $<0.0001$, respectively). Fridericia caudigera showed a lower $\mathrm{d}_{\text {pit }}$ in the stem than F. dispar and F. chica $(\mathrm{F}=6.527, p<$ $0.0001 ; \mathrm{F}=9.389, p<0.0001$, respectively; Tab. 1$)$. We did not find differences in the $\mathrm{d}_{\text {pit }}$ of the branches $(\mathrm{F}=1.025$; $p=0.74)$, stems $(\mathrm{F}=2.863 ; p=0.11)$, and roots $(\mathrm{F}=1.715$; $p=0.44)$ between F. dispar and F. chica.

$\mathrm{N}_{\text {pit }}$ in F. caudigera did not differ among the branches, stem, and roots $(\mathrm{F}=2.952 ; p=0.06 ;$ Tab. 1$)$. The $\mathrm{N}_{\text {pit }}$ differed among all organs analyzed in $F$. dispar $(\mathrm{F}=23.7$; $p<0.0001$ ), showing higher $\mathrm{N}_{\text {pit }}$ in the branches and lower $\mathrm{N}_{\text {pit }}$ in the stem (Tab. 1). The $\mathrm{N}_{\text {pit }}$ was higher in the branches and roots than in the stem for F. chica (Tab. 1). In this species, the $\mathrm{N}_{\text {pit }}$ was different between branches and the stem $(\mathrm{F}=$ 9.666; $p<0.0001)$ and between roots and the stem $(\mathrm{F}=7.192$; $p<0.0001)$. However, we did not find differences in $\mathrm{N}_{\mathrm{pit}}$ between branches and roots in F. chica $(\mathrm{F}=2.472 ; p=0.20)$.

The three species had similar WD $(\mathrm{F}=2.531, p=$ 0.0983; Tab. 1). WD correlated negatively with $\mathrm{A}_{\mathrm{V}}\left(\mathrm{r}^{2}=0.36\right.$; $r=-0.60$; Fig. $4 \mathrm{~A})$ and positively with $\mathrm{A}_{\mathrm{F}}\left(\mathrm{r}^{2}=0.28 ; r=+0.53\right.$; Fig. 4B) for all species. We did not find a correlation between WD and $\mathrm{A}_{\mathrm{p}}\left(\mathrm{r}^{2}=3 \mathrm{E}-05 ; r=0.0\right.$; Fig. $\left.4 \mathrm{C}\right)$. The highest proportion of the cross-sectional area was occupied by parenchyma in roots, vessels in stems, and fibers in branches (Tab. 1).

Fridericia caudigera and $F$. dispar showed deep phloem wedges inserted in the secondary xylem and xylem areas among the wedges, thus forming a disjoint cambium (Fig. 5A-B). Fridericia chica showed tenuous phloem wedges (Fig. 5C). We observed that shallow arches are formed, which result from a limited activity of the areas of cambial variation.

\section{Discussion}

Mean conduit diameter at distal parts (branches and roots) of the three liana species were narrower than in stems, thus suggesting higher hydraulic safety in branches and roots. Conduit tapering appears to be universal in tree hydraulic systems, and plants frequently show a decrease in hydraulic safety from branches to roots (Anfodillo et al. 2006; McCulloh et al. 2012). However, the arrangement of vessel density and diameter observed in the roots, stems, and branches of the lianas observed in the current study differed from those of other growth habitats. We observed that the xylem attributes of these lianas provide them with lower $\mathrm{K} p$ and higher hydraulic safety in roots. Narrower vessels in roots were also associated with a large amount of parenchyma, a tissue that is commonly involved in 


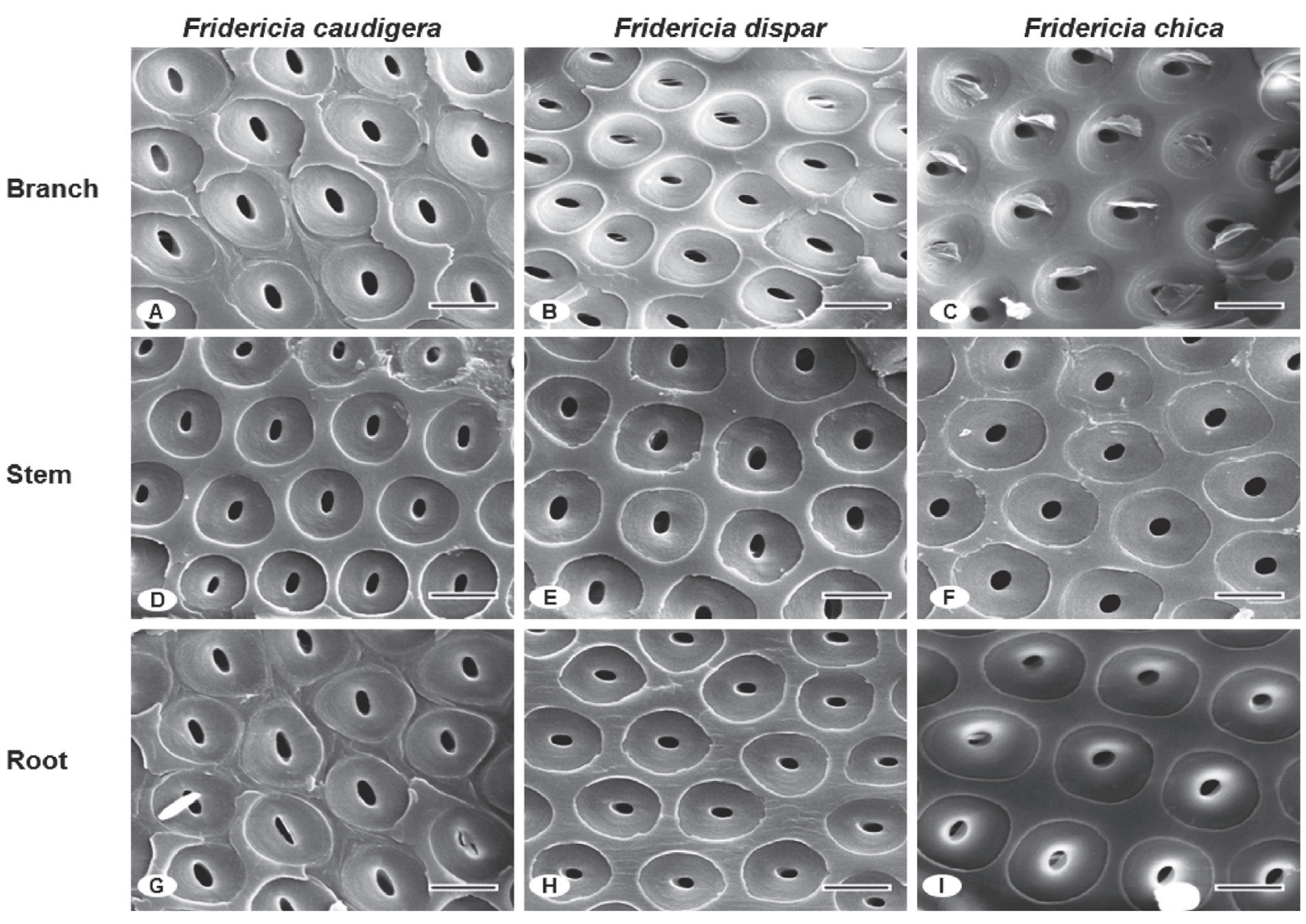

Figure 3. Pit vessel walls in Fridericia lianas. Fridericia caudigera found in the caatinga: (A) branch, (D) stem, and (G) root; F. dispar found in the Arenosol: (B) branch, (E) stem, and (H) root; and F. chica also found in the carrasco: (C) branch, (F) stem, and (I) root. Bars $=5 \mu \mathrm{m}$.

water and carbohydrate storage, which can be involved in osmoregulation and further increase the safety margin for embolism formation during drought (Carlquist 1985). These results suggest that a suite of anatomical traits can provide higher safety for water transport in roots of lianas inhabiting semiarid regions, thus allowing them to withstand low water potentials in soils during dry periods.

Although the vessel of the analyzed lianas does not have vestured pits, the pit diameters (approximately 1.1-1.6 $\mu \mathrm{m}$ ) were much smaller than those found by Brandes \& Barros (2008), which ranged from 5 to $10 \mu \mathrm{m}$ in moist forest liana species. According to Carlquist (1988) and Metcalfe \& Chalk (1989), pits with diameter smaller than $5 \mu \mathrm{m}$ are extremely small. We found that the decrease in $\mathrm{d}_{\text {pit }}$ determines an increase in $\mathrm{N}_{\text {pit }}$. On one hand, the increase of $\mathrm{N}_{\text {pit }}$ may imply a lower cavitation resistance because the occurrence and size of large pit membrane pores is thought to increase with the total pit membrane area per vessel (Wheeler et al.2005). On the other hand, membrane pores often have similar sizes among species, and the rare largest membrane pore per vessel determines the level of safety against cavitation (Choat et al. 2003). Thus, the smaller surface area of intervessel pits that we found may limit the area of the pit membrane and decrease the chance of occurrence of large pores in the membrane. We are assuming that narrow vessels with extremely small pits, mainly in the branches and roots of the lianas in the current study, are strong indicators of higher hydraulic safety; however, this contention still needs to be tested. Because the lianas are very sensitive to soil water decrease (see Clearwater \& Clark 2003) and atmospheric water stress, those growing in semiarid environments should have high resistance to cavitation in roots and branches associated with a water pressure increase in the xylem, thereby allowing the absorption and transport of water without inducing drastic hydraulic failures.

Despite of the lack of differences in WD in the stem, the differences in the other attributes among our species show that WD alone is not a good indicator of the hydraulic characteristics of lianas. High values of WD are frequently associated with a gain in resistance against embolism and with a reduction in hydraulic conductivity of the xylem (Hacke et al. 2001). However, our results show that WD is not related to the variation in hydraulic conductivity potential, and possibly, not to hydraulic safety of the liana.

The positive correlation between $\mathrm{WD}$ and $\mathrm{A}_{\mathrm{F}}$ and the negative correlation between WD and $\mathrm{A}_{\mathrm{v}}$ appear to be a common pattern for woody plants (Martinez-Cabrera et al. 2009; Poorter et al. 2010; Zanne et al. 2010). A larger $A_{v}$ gives rise to a higher porosity of xylem and thus a lower WD (McCulloh et al. 2012). We observed that an increase 

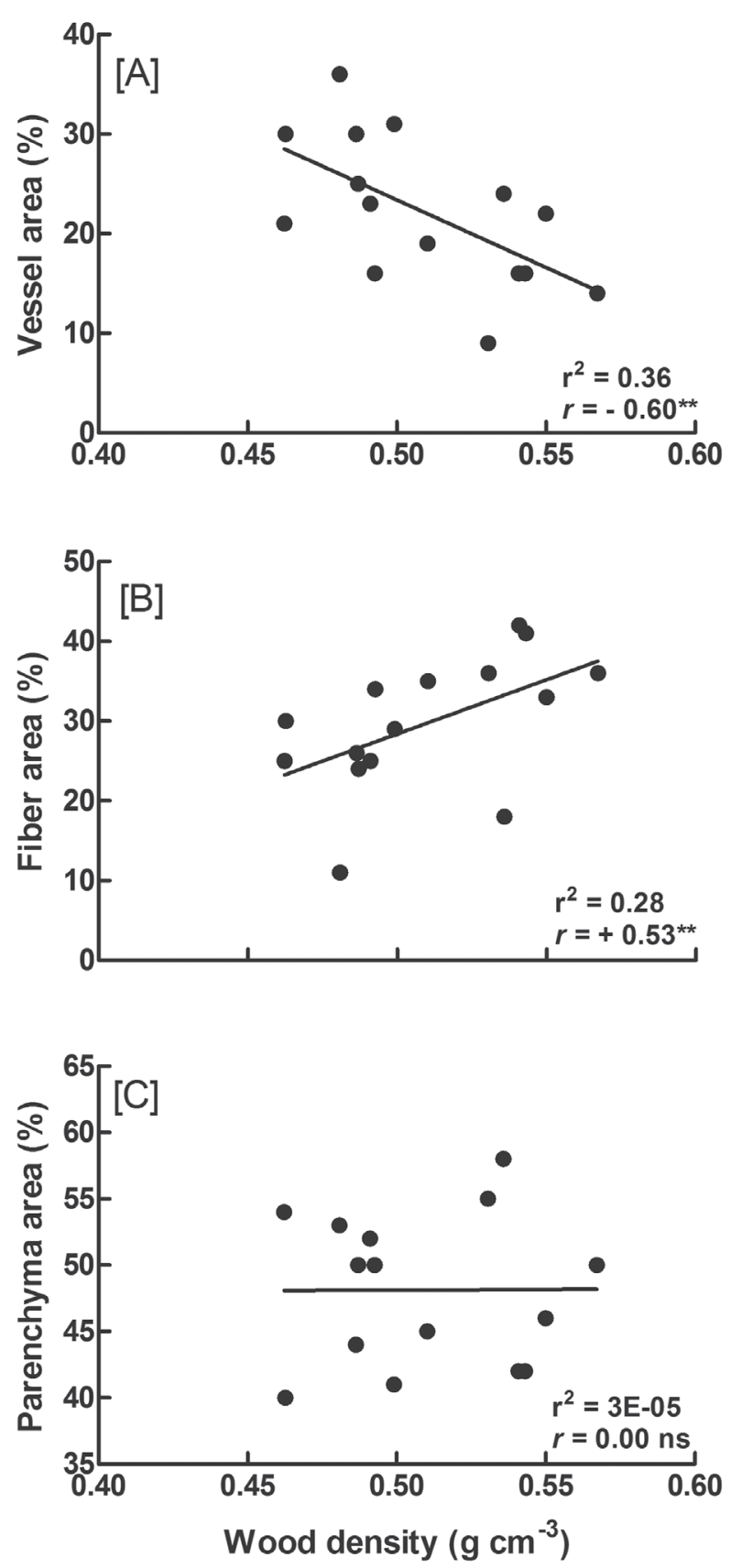

Figure 4. Relationship between wood density and the anatomical tissues that compose the xylem in Fridericia caudigera, F. dispar and F. chica. (A) Cross-sectional area occupied by vessels; (B) cross-sectional area occupied by fibers; (C) cross-sectional area occupied by parenchyma. Linear regressions, Pearson correlation $(r)$, significance levels $\mathrm{P}<0.05\left(^{*}\right)$ and $\mathrm{P}<0.01\left({ }^{*}\right)$, and not significant (ns) are shown.

in the porosity of wood in the stem, evidenced by $\mathrm{N}$ and the vessel average diameter (d), differed among the studied liana species but had always led to an increase in $\mathrm{K} p$ compared with that of branches and roots.

The distribution of xylem vessel diameter observed in the current study is typical for lianas (Carlquist 1985;
Gutiérrez et al. 2009; Rosell \& Olson 2014). Few wide vessels allow for a high $\mathrm{K} p$; however, these vessels are only found in parts of the stem. In the current study, over 70\% of the vessels fell into the first diameter classes. Although the predominance of narrow vessels in the branches and roots of the studied liana species resulted in a lower $\mathrm{K} p$, it could potentially increase the hydraulic safety (Gutiérrez et al. 2009; Abrantes et al. 2013). Although liana xylem is able to transport large volumes of water (Carlquist 1985; Carlquist 2012), the high percentage of narrow vessels indicate that they also have hydraulic safety. We evidenced these characteristics mainly in the roots, which are responsible for water absorption directly from the soil, and in the branches, which conduct water directly to the leaves.

$\mathrm{N}$ has been considered a secondary strategy to enhance $\mathrm{K} p$. However, we found a weak correlation between these attributes, probably because cross-sectional areas with vessels of similar diameter have different vessel density, thus indicating a weak trade-off between vessel diameter and density in our species. This pattern differs from what is generally described for woody species (Gartner et al. 1990; Poorter et al. 2010; McCulloh et al. 2012). We attributed the weak correlation between $\mathrm{N}$ and $\mathrm{K} p$ to the vessel dimorphism described by Carlquist (1985) in lianas. The vessels in lianas tend to be very wide or very narrow (Carlquist 1985; Lima et al. 2010; Carlquist 2012; Rosell \& Olson 2014) in contrast to the normal distribution expected for a population of cells (Carlquist 1985). In short, the simultaneous presence of wide and narrow vessels (vessel dimorphism) assures both efficiency and safety of hydraulic conductivity in lianas (Gutiérrez et al. 2009).

The different types of cambial variation recorded in $F$. chica and F. dispar, which co-occur in Arenosol, resulted in differences in vessel diameter, vessel density, and hydraulic conductivity. These differences may favor the co-occurrence of $F$. chica and $F$. dispar because differences in hydraulic architecture may decrease interspecific competition and favor coexistence (McCulloh et al. 2012). The most recent species of the tribe Bignonieae show deep wedges, which are similar to those observed in F. dispar and F. caudigera. However, because F. chica is ca. 10 million years more recent than F. dispar, its shallower wedges would represent a return to the most basal state of the clade (Pace et al. 2009; Lohmann et al. 2013).

Despite the spatial segregation between $F$. caudigera (found in the caatinga Leptosol) and F. dispar (found in the carrasco Arenosol), the cambial variation pattern is similar in both species, thus suggesting phylogenetic correlation (Pace et al. 2009; Lohmann et al. 2013) and phylogenetic conservatism of xylem anatomical characteristics. This fact implies that the geographic distribution and abundance of these species could not only be explained by dispersal filters but also by environmental filters, considering their capacity of using the resources available in each environment. 

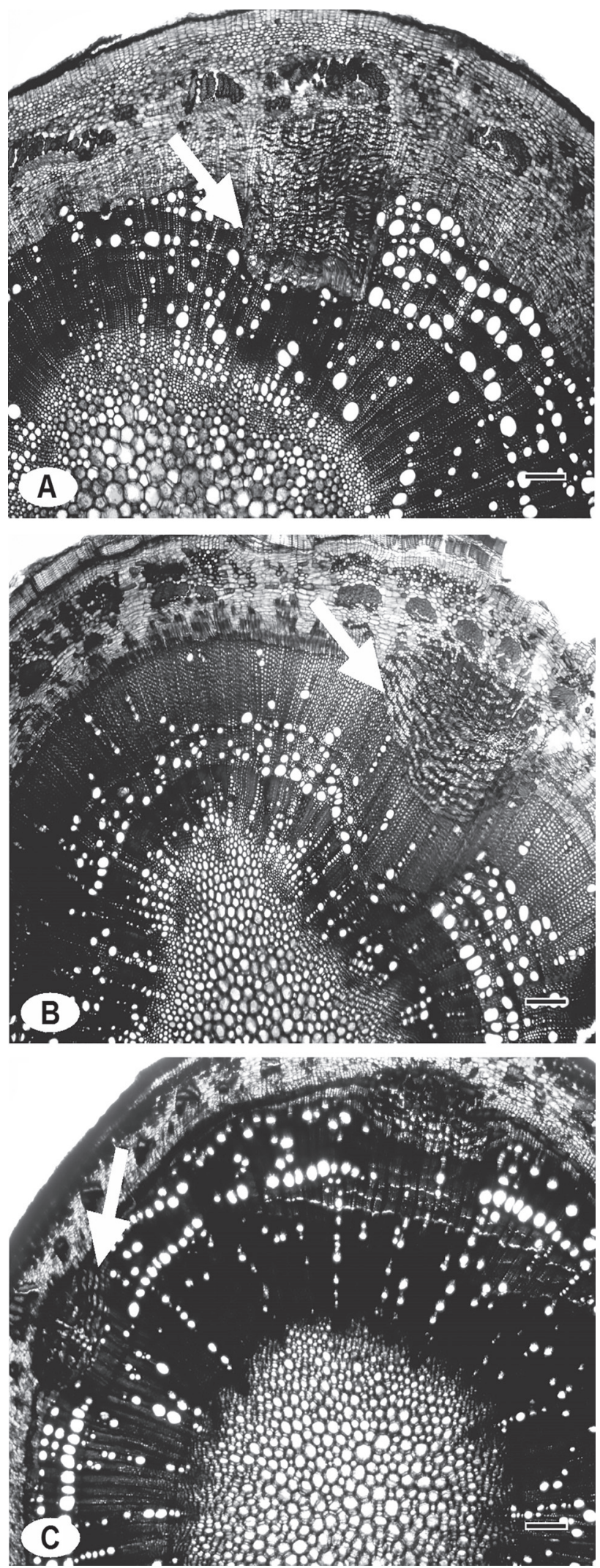

Figure 5. Anomalous secondary growth in branches of Fridericia lianas. (A) Fridericia caudigera found in the Leptosol; (B) F. dispar found in the caatinga; and (C) F. chica, both found in the carrasco. White arrows indicate areas of cambial variation in each species. Bars $=200 \mu \mathrm{m}$.

\section{Conclusions}

Lianas in semiarid environments possess a number of the following xylem traits that may allow resistance to tension-induced cavitation along the root-stem-branch continuum: 1) higher hydraulic safety in roots and branches; 2) dimorphic vessels, both efficient as safety hydraulic; and 3) small diameter of pits, at least five orders of magnitude smaller than those in lianas of moist forest. The anatomical characteristics of lianas indicate that their hydraulic functioning differs from that recorded in other growth habitats, in which hydraulic safety decreases progressively from branches to roots. The liana species that we studied have two hydraulic safety zones: one in the roots and other in the branches. Narrower vessels were associated with a large amount of parenchyma in roots, a tissue that may play a role in osmoregulation and water storage capacity, whereas narrower vessels were associated with a high proportion of fibers in branches, which can increase the strength of the xylem. Theses xylem attributes generate lower Kp and higher hydraulic safety in roots and branches, thus allowing the absorption and conduction of water under low water potential in the soil during drought.

\section{Acknowledgments}

We thank the Brazilian Council for Technological and Scientific Development (CNPq) for granting E.C.D. Carvalho a $\mathrm{PhD}$ scholarship and financial support. The Coordination for the Improvement of Higher Education Personnel (CAPES) through the National Program for Academic Cooperation provided E.C.D, Carvalho with financial support during her Sandwich PhD internship at the State University of Campinas (UNICAMP/São Paulo). We are grateful to CNPq for providing research grants to F. R. Martins, F. S. Araújo, and R. S. Oliveira. We thank B.C. Souza and C.C. Oliveira for their help in fieldwork. We also thank the staff of Serra das Almas Reserve for allowing us to work in the sites under their supervision and for the logistic support.

\section{References}

Abrantes J, Campelo F, García-Gonzalez I, Nabais C. 2013. Environmental control of vessel traits in Quercus ilex under Mediterranean climate: relating xylem anatomy to function. Trees 27: 655-662.

Anfodillo T, Carraro V, Carrer M, Fior C, Rossi S. 2006. Convergent tapering of xylem conduits in different woody species. New Phytologist 169: 279-290.

Angyalossy V, Angeles, G, Pace MR, et al. 2012. Na overview of the anatomy, development and evolution of the vascular system of lianas. Plant Ecology \& Evolution 5: 167-182.

Araújo FS, Martins RF. 1999. Fisionomia e organização da vegetação do carrasco no planalto da Ibiapaba, estado do Ceará. Acta Botanica Brasilica 13: 1-14.

Araújo FS, Costa RC, Lima JR, et al. 2011. Floristics and life-forms along a topographic gradient, central-western Ceará, Brazil. Rodriguésia 62: $341-366$ 
Barbosa RI, Fearnside PM. 2004. Wood density of trees in open savannas of the Brazilian Amazon. Forest Ecology and Management 199:115-123.

Brandes AFN, Barros CF. 2008. Anatomia do lenho de oito espécies de lianas da família Leguminosae ocorrentes na Floresta Atlântica. Acta Botanica Brasilica 22: 465-480.

Bucci SJ, Goldstein G, Meinzer FC, Scholz FG, Franco AC, Bustamante M. 2004. Functional convergence in hydraulic architecture and water relations of tropical savana trees: from leaf to whole plant. Tree Physiology 24: 891-899.

Carlquist S. 1985. Observations on functional wood histology of vines and lianas: vessel dimorphism, tracheids, vasicentric tracheids, narrow vessel, and parenchyma. ALISO 11:139-157.

Carlquist S. 1988. Comparative wood anatomy: systematic, ecological and evolutionary aspects of dicotyledons wood. Berlin, Springer-Verlag.

Carlquist S. 1989. Wood anatomy of Tasmanni: Summary of wood anatomy of Winteraceae. ALISO 12: 257-275.

Carlquist S. 2012. How wood evolves: a new synthesis. Botany 90: 901-940.

Chave J, Coomes D, Jansen S, Lewis SL, Swenson NG, Zanne AE. 2009. Towards a worldwide wood economics spectrum. Ecology Letters 12: 351-366.

Choat B, Ball M, Luly J, Holtum J. 2003. Pit membrane porosity and water stress-induced cavitation in four co-existing dry rainforest tree species. Plant Physiology 131: 41-48.

Choat B, Ball MC, Luly JG, Holtum JAM. 2005. Hydraulic architecture of deciduous and evergreen dry rainforest tree species from north-eastern Australia. Trees 19: 305-311.

Clearwater M, Clark CJ. 2003. In vivo magnetic resonance imaging of xylem vessel contents in wood lianas. Plant, Cell and Environment 26: 1206-1214.

Costa RC, Araújo FS. 2012. Physiognomy and structure of a caatinga with Cordia oncocalyx (Boraginaceae), a new type of community in Andrade-Lima's classification of caatingas. Rodriguésia 63: 269-276.

Ewers FW, Cochard H, Tyree MT. 1997. A survey of root pressures in vines of a tropical lowland forest. Oecologia 110: 191-196.

FAO - Food and Agriculture Organization. IUSS Working Group WRB. 2007. World Reference Base for Soil Resources 2006. World Soil Resources Reports. $\mathrm{N}^{\circ} 103$. Rome, FAO.

Gartner BL, Bullock SH, Mooney HA, Brown V, Whitbeck JL. 1990. Water transport properties of vine and tree stems in a tropical deciduous forest. American Journal of Botany 77: 742-749.

Gea-Izquierdo G, Fonti P, Cherubini P, Martín-Benito D, Chaar H, Cañellas I. 2012. Xylem hydraulic adjustment and growth response of Quercus canariensis Willd. to climatic variability. Tree Physiology 23: 401-413.

Gerlach D. 1984. Botanische Mikrotechnik. Stuttgart, Georg Thieme Verlag.

Gutiérrez M, Miguel-Chávez RS, Terrazas T. 2009. Xylem conductivity and anatomical traits in diverse lianas and small tree species from a tropical forest of southwest Mexico. International Journal of Botany 5: 279-286.

Hacke UG, Sperry JS. 2001. Functional and ecological xylem anatomy. Perspectives in Plant Ecology, Evolution and Systematics 4: 97-115.

Hacke UG, Sperry JS, Pockman WT, Davis SD, McCulloh KA. 2001. Trends in wood density and structure are linked to prevention of xylem implosion by negative pressure. Oecologia 126: 457- 461.

Hacke UG, Sperry JS, Wheeler JK, Castro L. 2006. Scaling of angiosperm xylem structure with safety and efficiency. Tree Physiology 26: 689701.

Hammer O, Harper DA, Rian PD. 2001. Past: Paleontological statistics software package for education and data analysis. Version 2.17. Palaeontologia Electronica 4: 9pp. http://palaeo-electronica.org/2001_1/ past/issue1_01.htm

Jacobsen AL, Pratt RB, Davis SD, Ewers FW. 2008. Comparative community physiology: nonconvergence in water relations among three semi-arid shrub communities. New Phytologist 180: 100-113.
Jacobsen AL, Pratt RB, Tobin MF, Hacke UG, Ewers FW. 2012. A global analysis of xylem vessel length in woody plants. American Journal of Botany 99: 1583-1591.

Junqueira CU. 1990. O uso de cortes finos de tecidos na medicina e biologia. Meios e Métodos 66: 167-171.

Lima AC, Pace MR, Angyalossy V. 2010. Seasonality and growth rings in lianas of the Bignoniaceae. Trees 24: 1045-1060.

Lohmann LG, Bell CD, Calió MF, Winkworth RC. 2013. Pattern and timing of biogeographical history in the Neotropical tribe Bignonieae (Bignoniaceae). Botanical Journal of the Linnean Society 171: 154-170.

Martínez-Cabrera HI, Jones, CS, Espino S, Schenk HJ. 2009 Wood anatomy and wood density in shrubs: responses to varying aridity along transcontinental transects. American Journal of Botany 96: 1388-1398.

McCulloh KA, Johnson DM, Meinzer FC, Voelker SL, Lachenbruch B, Domec JC. 2012. Hydraulic architecture of two species differing in wood density: opposing strategies in co-occurring tropical pioneer trees. Plant, Cell and Environment 35: 116-125.

McCulloh KA, Meinzer FC, Sperry JS, et al. 2011. Comparative hydraulic architecture of tropical tree species representing a range of successional stages and wood density. Oecologia 167: 27-37.

McCulloh KA, Sperry JS, Lachenbruch B, Meinzer FC, Reich PB, Voelker S. 2010. Moving water well: comparing hydraulic efficiency in twigs and trunks of coniferous, ring-porous and diffuse-porous saplings from temperate and tropical forests. New Phytologist 186: 439-450.

McCulloh KA, Sperry JS. 2005. Patterns in hydraulic architecture and their implications for transport efficiency. Tree Physiology 25: 257-267.

Metcalfe CR, Chalk L. 1989. Anatomy of the Dicotyledons: Wood structure and conclusion of the general introduction. New York, Oxford University Press.

Mitchell PJ, Veneklaas EJ, Lambers H, Burgess SSO. 2008. Using multiple trait associations to define hydraulic functional types in plant communities of south-western Australia. Oecologia 158: 385-397.

Pace MR, Lohmann LG, Angyalossy V. 2009. The rise and evolution of the cambial variant in Bignonieae (Bignoniaceae). Evolution \& Development 11: 465-479.

Poorter L, McDonald I, Alarcón A, et al. 2010.The importance of wood traits and hydraulic conductance for the performace and life history strategies of 42 rainforest tree species. New Phytologist 185: 481-492.

Pratt RB, Jacobsen AL, Golgotiu KA, Sperry JS, Ewers FW, Davis SD. 2007. Life history type and water stress tolerance in nine California chaparral species (Rhamnaceae). Ecological Monographs 77: 239-253.

Rosell JA, Olson ME. 2014. Do lianas really have wide vessels? Vessel diameter-stem length scaling in non-sef-supporting plants. Perspectives in Plant Ecology, Evolution and Systematics 16: 288-295.

Sperry JS, Hacke UG. 2002. Desert shrub water relations with respect to soil characteristics and plant functional type. Functional Ecology 16: $367-378$

Tyree MT, Ewers FW. 1991. The hydraulic architecture of trees and other woody plants. New Phytologist 119: 345-360.

Vasconcelos SF, Araújo FS, Lopes AV. 2010. Phenology and dispersal modes of wood species in the Carrasco, a tropical deciduous shrubland in the Brazilian semiarid. Biodiversity and Conservation 19:2263-2289.

Wheeler JK, Sperry JS, Hacke UG, Hoang N. 2005. Inter-vessel pitting and cavitation in woody Rosaceae and other vesselled plants: a basis for a safety versus efficiency trade-off in xylem transport. Plant, Cell and Environment 28: 800-812.

Wiens JJ, Graham CH. 2005. Niche conservatism: Integrating evolution, ecology, and conservation biology. Annual Reviews Ecology, Evolution and Systematic 36: 519-539

Zanne AE, Westoby M, Falster DS, et al. 2010. Angiosperm wood structure: Global patterns in vessel anatomy and their relation to wood density and potential conductivity. American Journal of Botany 97: 207-215.

Zimmermann MH. 1983. Xylem Structure and the Ascent on Sap. Berlin, Springer-Verlag. 